\title{
International Journal of Business, Economics and Social Development
}

Vol. 2, No. 2, pp. 50-56, 2021

\section{Determinants of Socio Economic and Demographic Characteristics of Poverty in Aceh Province}

\author{
Heri Wintara, Raja Masbar and Suriani \\ Faculty of Economic and Business, Universitas Syiah Kuala, Banda Aceh, Indonesia \\ *Corresponding author email: heri.wintara@gmail.com
}

\begin{abstract}
This study analyzes the effect of socio-economic and demographic characteristics on poverty levels in Aceh Province in the short and long run. Socio-economic characteristics are represented by factors of income per capita, open unemployment rate, and cigarette consumption. While the demographic characteristics are represented by the dependency ratio factor. This study uses panel data from 23 districts/cities in Aceh Province for the 2010-2019 period and the analysis model used is the Autoregressive Distributed Lag (ARDL) panel model. The results found in this study are the dependency ratio factor, cigarette consumption, and the open unemployment rate have a significant effect in the long run on the percentage of poor people. Meanwhile, the significant factors in the short run are the dependency ratio and the open unemployment rate.
\end{abstract}

Keywords: poverty, dependency ratio factor, cigarette consumption

\section{Introduction}

Poverty is a complex and multidimensional problem, where poverty is closely related to social, economic, cultural, political and other aspects (Warr, 2005; Pusra et al., 2021; Maulana et al., 2020). The phenomenon of poverty almost occurs in all countries, especially in poor and developing countries. It is not surprising that poverty is one of the targets on the sustainable development agenda or the Sustainable Development Goals (SDGs), namely the first goal with the target: Eradicating extreme poverty (people below the poverty line) with purchasing power of less than $\$ 1.25$ PPP (Purchasing Power Parity). ) and by 2030 reduce at least half of the number of poor people (men, women and children of all ages) based on national definitions (SDGs Indonesia). The Central Statistics Agency defines poverty as a deprived living condition experienced by someone who has a per capita expenditure for a month that is not sufficient to meet the minimum standard of living needs (Yunus, 2019).

Indonesia itself is still categorized as a developing country, no wonder the problem of poverty in almost all regions is still the main focus in development. Based on BPS data, the percentage of poor people in Indonesia in 2019 (September conditions) was 9.22 percent or around 24.78 million people. From this value, Aceh Province ranks 6th out of 34 provinces with the highest percentage of poverty rates at 15.01 percent or around 809.76 thousand people.The high rate of poverty will have an impact on the inability of the community to access education, health, and decent living conditions so that in the long run it results in the low quality of Human Resources (HR) and hinders development. The poverty condition of a country or region is a reflection of the level of welfare of the population living in that country or region (Dewi et al., 2018).

The area with the highest percentage of poor people in Aceh Province is Aceh Singkil Regency which has a percentage of poor people of 20.78 percent while the area with the lowest percentage of poor people is Banda Aceh City, namely by 7.22 percent. In total, there are 13 districts/cities that have a higher percentage of poor people than the percentage of poor people in Aceh Province. When compared with the percentage of poor people nationally, only Banda Aceh City has a lower percentage of poor people. This is certainly an evaluation of poverty alleviation programs that still require serious and structured handling. 
Conceptually, poverty itself is divided into two types, namely relative poverty and absolute poverty. BPS calculates poverty using the concept of absolute poverty through the basic needs approach, both food and non-food. This approach is more stable where the value remains in the standard of living so that comparisons can be made with other regions or other countries. Meanwhile, the relative approach is determined/determined subjectively by the economic conditions of the local community and is local in nature so that it cannot be compared between regions (Pratama and Rahadiana, 2020).

Economists also define poverty more broadly than simply a person's lower level of income or consumption from a measured welfare standard such as the minimum calorie requirement or the poverty line. However, poverty has a deeper meaning because it is related to the inability to achieve non-income factors such as access to minimum needs; health, education, clean water, and sanitation (Jalil et al., 2019).

Santika et al. (2021) said that one of the problems experienced by every country in the world seriously is poverty. Based on the patterns and characteristics of poverty that have been described, in general, apart from the characteristics of poverty, it can be classified in terms of both socio-economic and demographic aspects. Socio-economic characteristics are characteristics that are generally attached to the subject of the poor both individually and in families as well as characteristics based on environmental conditions, such as education level, income level, type of work, employment status, access, housing conditions and environmental conditions. In addition, the level of cigarette consumption also affects the level of poverty in an area. While the demographic characteristics include age, gender, number of household members and the number of dependent burdens of household members in the family.

Research on unemployment and poverty rates has been carried out by Quy (2016). By using panel data from 63 provinces in Vietnam from 2013 to 2015 and using the Linear Regression method, the results show that the unemployment rate is negatively and significantly related to poverty in Vietnam, when unemployment increases poverty actually decreases because unemployment is more in urban areas while the population is poor. more in rural areas. Afif and Sasana (2019) in their research stated that there is a relationship between the level of poverty and the level of one's cigarette consumption. In his research which is interesting is his finding which states that cigarette consumption will make a person tend to be poor. In addition, the journal published by the Ministry of Health of the Republic of Indonesia (2018) also states that cigarette consumption will increase disparities both from the health and economic aspects where the community groups who feel the most impact are low-income groups. WHO (2017) says that there tends to be a decline in the country's economic development due to an increase in the poverty rate caused by the high consumption of cigarettes.

The relationship between dependency ratio and poverty has been carried out by (Chaudhry et al., 2010) in Pakistan. The data comes from household surveys in the village of Chah Qaisar, Kande Wala in Betti Nala, Tehsil Jatoi and Muzaffargarh district, using a log linear regression model, the results show that Dependency Ratio has a positive and significant relationship to poverty in Pakistan. The higher the dependency ratio, the poverty will increase. In addition, the research conducted by Wulandari (2019) regarding the relationship between the dependency ratio and the poverty level in Sragen Regency stated that there was an influence given by the dependency ratio on the poverty level in Sragen Regency.

In this study, the variables of socio-economic characteristics that are considered to have an effect on poverty are income per capita, open unemployment rate, and cigarette consumption. While the variables of demographic characteristics are represented by the dependency ratio variable. Taking the income per capita variable because this variable is a general description to be able to approach the poverty level. The open unemployment variable and the dependency ratio are variables that explain how a person fulfills his needs so that these variables are expected to be able to explain the level of poverty. The last variable is the cigarette consumption variable, which is an illustration of the characteristics of the population of Aceh Province where the expenditure is the second largest after rice consumption, but cigarette consumption is not able to add calories, so it is interesting to see whether cigarette consumption can affect poverty levels.

\section{Literature Review}

\subsection{Poverty}

The definition according to the United Nations Development Program (2000), poverty is a situation where a person or household has difficulty meeting basic needs, while the supporting environment does not provide opportunities to improve welfare on an ongoing basis or to get out of vulnerability. The Central Bureau of Statistics (2015), defines poverty as an inability from an economic perspective to meet basic food and non-food needs as measured from the expenditure side. So, the poor are people who have an average monthly per capita expenditure below the poverty line. While the poverty line is the sum of the food poverty line (GKM) and the non-food poverty line (GKNM). The Food Poverty Line (GKM) is the value of spending on minimum food needs which is equivalent to 2100 kilocalories per 
capita per day. While the Non-Food Poverty Line (GKNM) is defined as the minimum need for housing, clothing, education and health.

The poverty approach taken by BPS in calculating the poverty line based on income measures, where the poverty line is calculated from the number of rupiah spent per capita per month to meet the minimum food and non-food needs. The main data source used is data from the National Socio-Economic Survey for the Consumption and Expenditure Module.

\subsection{Socio-Economic Characteristics}

Socio-economic characteristics have a very broad meaning, so in this study they are limited to several variables that are considered to have an effect on poverty. The first variable is income per capita which is basically the level of the economy in an area compared to the total population in that area in a certain period of time. Per capita income can also describe the added value generated by each resident by means of the production process. Per capita income is often used as a benchmark that is able to describe the level of welfare of the population in an area. When per capita income increases, the ability of the community to meet their needs also increases so that it will increase the prosperity of the community itself. This of course will have an impact on reducing the level of poverty in an area (Kirkbride et al., 2008).

The income per capita has a negative and significant effect on poverty. Per capita income is able to describe the economic level of the population in a region (Ncube et al., 2014). Sepulveda and Martinez-Vazquez (2011) states that the higher the level of income per capita in a region, the greater the potential for regional income, which shows that the level of welfare of the population is also increasing which has an impact on the decline in the poor.

Furthermore, the socio-economic variable used is the open unemployment rate where this variable explains how the population is able to generate income so that they are able to cover their needs. A high level of budgeting will have an impact on decreasing people's welfare and increasing economic inequality within a country. Saunders (2002) conducted a study on a group of unemployed and working people. The results show that in addition to feeling less in terms of income, those who are unemployed also psychologically have lower scores on self-acceptance and the environment.

While the last socio-economic variable is the cigarette consumption variable. This variable is used because one of the socio-economic characteristics inherent in the population of Aceh Province is cigarette consumption. This is because cigarette consumption is the largest food expenditure after rice. BPS said that if the poor people switched their consumption of cigarettes to consumption of other foods that have calories, there is a possibility that they will not be poor. The Indonesian Parliamentarians Forum for Population and Development (IFPPD) conducted a study on cigarette consumption patterns among the poor in Indonesia and found that two out of three fathers in Indonesia consume cigarettes. The results of their estimates that there will be as many as 12 million fathers from 19 million poor families are smokers. In Indonesia, the number of active smokers is higher among people with low incomes. Poor families are more concerned with the needs of cigarettes than other food needs that have nutritional value.

\subsection{Demographic Characteristics}

Demography comes from the Greek language which has the meaning of writing or writing about the people (Julkhaidar et al., 2020). According to the International Union for Scientific Study of Population or IUSSP (1982), demography is a science that studies population, especially regarding the number, population structure, characteristics, and development. The variable that is considered to represent the demographic characteristics is the dependency ratio. The dependency ratio is the ratio between the total population aged 0-14 years, plus the population 65 years and over (both referred to as non-labor force) compared to the total population aged 15-64 years (labor force). The dependency ratio is used as an indicator that can roughly show the economic condition of a country whether it is classified as a developed country or a developing country. The dependency ratio is an important demographic indicator. The higher the percentage of the dependency ratio indicates the higher the burden that must be borne by the productive population to finance the lives of the unproductive and unproductive population. Meanwhile, the lower percentage of the dependency ratio indicates the lower the burden borne by the productive population to finance the unproductive and unproductive population.

In addition to being inactive in the labor market, non-productive age residents are also generally dependent on their families both in terms of economy and health. Akerele and Adewuyi (2011) conducted a study on 80 households in the state of Ekiti, Nigeria to see the poverty profile in these households and using the OLS method found that the dependency ratio was negatively related to poverty where poorer households tend to have a higher dependency ratio. high or have a large burden of non-productive family members. 


\section{Materials and Methods}

This study aims to analyze how socio-economic and demographic characteristics variables can influence poverty in Aceh Province. The data structure used in this study is panel data, namely a cross-section of 23 districts/cities in Aceh Province and time series for the period 2010 - 2019. The data used in this study is secondary data obtained from the Central Statistics Agency.

The model used is the Auto Regressive Distributed Lag (ARDL) model. The ARDL model is used to be able to answer whether the independent variable has an effect on the dependent variable both in the short and long run. This method is used to answer the research objectives to be able to see how the variables of income inequality, open unemployment rate, cigarette consumption, and the dependency ratio to poverty in Aceh Province are in the short and long run. In its application, the ARDL model is not concerned with the degree of integration of each variable so that this method is able to eliminate the element of uncertainty (Nkoro and Uko, 2016).

The ARDL models proposed in this study are:

$$
\begin{gathered}
P M_{i, t}=\beta_{0}+\varphi_{1} P K_{i, t}+\ldots+\varphi_{q} P K_{i, t-q}+\varphi_{1} T P T_{i, t}+\ldots+\varphi_{q} T P T_{i, t-q}+\varphi_{1} K R_{i, t}+\ldots+\varphi_{q} K R_{i, t-q} \\
+\varphi_{1} R K_{i, t}+\ldots+\varphi_{q} R K_{i, t-q}
\end{gathered}
$$

Where:

$$
\begin{array}{ll}
\text { PM } & \text { : Percentage of poor people } \\
\text { PK } & \text { : Income per capita } \\
\text { TPT } & \text { : Open unemployment rate } \\
\text { KR } & \text { : Cigarette consumption } \\
\text { RK } & \text { : Dependency ratio }
\end{array}
$$

In conducting the analysis using the ARDL method, it is necessary to do a stationarity test. Stationarity test is used to find out whether the data from each variable used in a study has a stable trend or not. In its application, data that has time series elements has a tendency to be unstable or non-stationary where the data used has a unit root, namely the average value and the variance changes throughout the time of observation. The data is not stationary if used in the regression equation will result in spurious regression or spurious regression so that the resulting estimation results will be wrong. The test used in the stationarity test is the Levin, Lin \& Chu (LLC) test. After the data is stationary, then proceed with the cointegration test. This test is used in order to see the cointegration relationship formed between the variables studied. Baltagi (2005) says that the cointegration test for panel data can use the Pedroni test which is classified into 2 categories. The first involves the statistical mean value for cointegration in time series data against cross section data. The second category is the individual mean of each cross-section.

\section{Results and Discussion}

Before analyzing the panel data ARDL model, it is necessary to test the stationarity of the data. In conducting the stationarity test, the unit root test is used or called the unit root test. This test was introduced by Dickey-Fuller so it is also called the DF unit root test. In this study, the test used was the Levin, Lin, and Chu (LLC) test. The first step of the stationarity test is a test at the level where the results of the stationary test at the level indicate that there are still non-stationary variables, namely income per capita, cigarette consumption, and dependency ratio, so it is necessary to test stationarity at the first difference level of these variables. After doing the stationarity test at the first difference level, it was found that all variables were stationary so that it could be continued to the stationarity test. Cointegration test in this study used the Pedroni test. The results of the pedronic test indicate that there has been cointegration or long-term equilibrium of each variable used in this study. The next step after the cointegration test is done is an analysis of the ARDL model that is formed both in the short and long run.

The Long-term estimation is one of the advantages of using the ARDL model. The ARDL analysis model for long-term panel data formed can be seen in Table 1.

Table 1. ARDL Data Panel Estimation Results in the Long run

\begin{tabular}{ccccc}
\hline Variable & Coefficient & Std. Error & t-Statistic & Prob* $^{*}$ \\
\hline RK & 2.614899 & 0.300162 & 8.711626 & $0.0000^{*}$ \\
\hline PK & 0.075805 & 0.073031 & 1.037984 & 0.3021 \\
\hline TPT & -0.438855 & 0.052271 & -8.395816 & $0.0000^{*}$ \\
\hline KR & 0.000027 & $8.53 \mathrm{E}-06$ & 3.114802 & $0.0025^{*}$ \\
\hline
\end{tabular}


* Significant at $\alpha=5 \%$

Based on the Table 1, it can be shown that of all the independent variables studied in this study, there are 3 variables that have a significant effect on the poverty level in Aceh Province. Those variables are dependency ratio, open unemployment rate, and cigarette consumption. Only the income per capita variable does not have a significant long-term effect on the level of poverty that occurred in Aceh Province during the study period.

The dependency ratio has a positive and significant effect on the poverty level at a tolerable error level of 5 percent. In addition, this variable is the variable that has the greatest influence on the poverty level in Aceh Province when compared to other variables studied in this study.

In line with the dependency ratio variable, the cigarette consumption variable also has a positive and significant influence on the poverty level. This effect is certainly an interesting finding because the expenditure on cigarette consumption can make a person tend to be in the poor population group. This is because the people of Aceh Province who smoke tend to be in the lower middle-income community while cigarettes do not have calories so that the food poverty line increases. This increase also has an effect on increasing the total poverty line which has an impact on increasing the number of poor people. This is also supported by research conducted by the Ministry of Health of the Republic of Indonesia (2018) which states that the smoking population in Indonesia is a low-income group and is one of the factors that causes a person to tend to be poor.

On the other hand, the variable open unemployment rate has a negative and significant effect on the poverty rate in Aceh Province in the long run. This states that when there is a decrease in the open unemployment rate, it will increase the poverty rate in Aceh Province. This is due to the high number of people who work but are still included in the group of unskilled workers so that a person's chance in Aceh Province to become a manual worker is greater than other employment opportunities in Aceh Province. Unskilled workers tend to earn relatively small incomes so that the chances of someone in Aceh Province to become poor tend to be greater. This is in accordance with research conducted by Yacoub (2012) in West Kalimantan Province. This study found that in addition to workers who have low incomes, the high number of family workers also has an impact on the negative influence given to the level of poverty where their status only helps generate income from family businesses.

Furthermore, the analysis carried out after analyzing the long-term model is a short-term analysis. The output of the ARDL panel data model for the short run can be seen in Table 2.

Table 2. ARDL Data Panel Estimation Results in the Short run

\begin{tabular}{ccccc}
\hline Variable & Coefficient & Std. Error & t-Statistic & Prob* $^{*}$ \\
\hline \multicolumn{5}{c}{ Short Run Equation } \\
\hline COINTEQ01 & -0.480286 & 0.076781 & -6.255307 & 0.0000 \\
\hline $\mathrm{D}(\mathrm{RK})$ & 3.374312 & 1.334597 & 2.528337 & $0.0132^{*}$ \\
\hline $\mathrm{D}(\mathrm{PK})$ & 0.992555 & 1.373827 & 0.722475 & 0.4719 \\
\hline $\mathrm{D}(\mathrm{TPT})$ & 0.066860 & 0.032378 & 2.064979 & $0.0419^{*}$ \\
\hline $\mathrm{D}(\mathrm{KR})$ & -0.000005 & $6.28 \mathrm{E}-06$ & -0.765436 & 0.4461 \\
\hline $\mathrm{C}$ & -61.36002 & 9.632691 & -6.369977 & 0.0000 \\
\cline { 2 - 5 } * Significant at $\alpha=5 \%$ & & &
\end{tabular}

The dependency ratio has a positive and significant relationship in the short run with a coefficient value of 3.374312, which means that every 1-unit increase can increase the percentage of poor people by 3.374312 percent. This result is in line with the findings from the long run where the dependency ratio has a positive and significant relationship with the percentage of poor people.

Next is the open unemployment rate where this variable has a positive and significant effect in the short run on the percentage of the poor. This result is inversely proportional to the results obtained in the long run. The effect given by this variable is 0.066860 percent, which means that every 1 percent increase in the open unemployment rate will cause an increase in the percentage of poor people in Aceh Province by 0.066860 percent.

\section{Conclussion}

The dependency ratio variable and cigarette consumption have a positive and significant effect in the long run on the percentage of poor people. The open unemployment rate has a negative and significant effect in the long run on the percentage of poor people. While the income per capita variable has a positive but not significant effect in the long run on the percentage of poor people in Aceh Province during the study period. 
In the short run, the variables that have a significant effect on the percentage of the poor are the dependency ratio and the open unemployment rate. The income per capita variable has a positive but not significant effect on the percentage of the poor population while cigarette consumption has a negative but not statistically significant effect in the short run in Aceh Province during the study period.

\section{References}

Afif, M. N., and Sasana, H. (2019). Pengaruh Kemiskinan, Pendapatan Per Kapita, Harga Rokok, Produksi Rokok Terhadap Konsumsi Rokok Di Indonesia. Diponegoro Journal of Economics, 1(1), 88-96.

Akerele, D., and Adewuyi, S. A. (2011). Analysis of poverty profiles and socioeconomic determinants of welfare among urban households of Ekiti State, Nigeria. Current Research Journal of Social Sciences, 3(1), 1-7.

Baltagi, B. H. (2005). Econometric Analysis of Panel Data, New York: John Wiley \& Sons, Ltd.

Chaudhry, I. S., Malik, S., Hassan, A., and Faridi, M. Z. (2010). Does education alleviate poverty? Empirical evidence from Pakistan. International Research Journal of Finance and Economics, 52, 134-141.

Dewi, E., Munawiyah, M., and Nurzalikha, S. (2018). Returning Government Policy for Poverty Reduction in Aceh. Budapest International Research and Critics Institute-Journal (BIRCI-Journal), 40-49.

Jalil, H., Yani, T. A., and Kurniawan, A. (2019). Optimization of Special Autonomy Funds Allocation to Alleviate Poverty in Aceh (A Case Study in Districts/Cities). Optimization, 9(4), 93-108.

Julkhaidar, R., Muhammad, Y., and Andy, M. (2020). Correlation analysis of rice attributes and socio demographic in Palembang, South Sumatera, Indonesia. World Journal of Advanced Research and Reviews, 5(2), 139-145.

Kirkbride, J. B., Barker, D., Cowden, F., Stamps, R., Yang, M., Jones, P. B., and Coid, J. W. (2008). Psychoses, ethnicity and socio-economic status. The British Journal of Psychiatry, 193(1), 18-24.

Maulana, A. R. R., Zulham, T., and Sartiyah, S. (2020). Aceh Province Economic Convergence Determination. International Journal of Business, Economics, and Social Development, 1(4), 212-226.

Ncube, M., Anyanwu, J. C., and Hausken, K. (2014). Inequality, economic growth and poverty in the Middle East and North Africa (MENA). African Development Review, 26(3), 435-453.

Nkoro, E., and Uko, A. K. (2016). Autoregressive Distributed Lag (ARDL) cointegration technique: application and interpretation. Journal of Statistical and Econometric methods, 5(4), 63-91.

Pratama, S. D., and Rahadiana, R. (2020). Muzakki Potentials' Role in Alleviating Poverty (Study Case in Aceh). International Journal of Islamic Economics and Finance (IJIEF), 3(1), 95-120.

Pusra, C. M., Srinita, S., and Seftarita, C. (2021). Effect of Selected Economic Sectors on Poverty. International Journal of Business, Economics, and Social Development, 2(1), 37-49.

Quy, N. H. (2016). Relationship between Economic Growth, Unemployment and Poverty: Analysis at Provincial Level in Vietnam. International Journal of Economics and Finance, 8(12), 113-119

Santika, T., Wilson, K. A., Law, E. A., St John, F. A., Carlson, K. M., Gibbs, H., and Struebig, M. J. (2021). Impact of palm oil sustainability certification on village well-being and poverty in Indonesia. Nature Sustainability, 4(2), 109-119.

Saunders, P. (2002). The direct and indirect effects of unemployment on poverty and inequality. Australian Journal of Labour Economics, 5(4), 507-529.

Sepulveda, C. F., and Martinez-Vazquez, J. (2011). The consequences of fiscal decentralization on poverty and income equality. Environment and Planning C: Government and Policy, 29(2), 321-343.

Warr, P. (2005). Food policy and poverty in Indonesia: a general equilibrium analysis. Australian Journal of Agricultural and Resource Economics, 49(4), 429-451. 
WHO. (n.d.). WHO Report on the Global Tobacco Epidemic 2017. Retrieved May 20, 2021, from http://www.who.int/tobacco/global_report/2017/en/\%0AWHO

Wulandari, A. I. P., Arif, M., and Dev, S. M. (2019). Hubungan Antara Dependency Ratio, Disparitas, Dan Aksesibilitas Terhadap Kemiskinan Di Kabupaten Sragen (Doctoral dissertation, Universitas Muhammadiyah surakarta).

Yacoub, Y. (2012). Pengaruh Tingkat Pengangguran terhadap Tingkat Kemiskinan Kabupaten / Kota di Provinsi Kalimantan Barat. Jurnal Eksos, 8(3), 176-185.

Yunus, S. (2019). Cooperation among farming stakeholders in farmers poverty reduction in aceh. International Journal of Innovation, Creativity and Change, 9(5), 177-186. 